\title{
A Comparison of Blackstrap Molasses Fortified with Soybean Oilmeal and a Conventional Concentrate Mixture as a Supplement for Growing Heifers Fed Fair-Quality Forage
}

\section{Paul F. Randel ${ }^{1}$ \\ INTRODUCTION}

Since replacement dairy heifers produce no immediate monetary return, they are often subjected to pasture management and given little or no supplementary feed, even during periods of drought when pastures provide very limited nutrient intakes. The result of this practice is a widespread occurrence of retarded growth in the replacement-heifer population. The employment of supplementary feeds for these animals, at least during periods of drought, would be desirable, but it is essential that the supplements be inexpensive. Since the large-scale production of harvested forages of suitable quality is not feasible in certain areas of Puerto Rico, economical feeding programs including concentrate feeds are needed. Therefore, the present experiment was undertaken to determine whether the feeding of replacement heifers between the ages of 4 and 12 months could be made less expensive by substituting molasses, plus a small amount of high-protein supplement, for a conventional mixture of concentrate feeds.

\section{REVIEW OF LITERATURE}

Blackstrap molasses compares favorably with conventional grains as an energy source for growing dairy heifers, provided it is not incorporated into the ration in excessive amounts, though the characteristics of the remainder of the ration have a decided effect upon the resulting growth rates. Bohman et al. (2) ${ }^{2}$ found it necessary to supplement poor-quality grass hay with 7.2 pounds of molasses plus 1.2 pounds of soybean oilmeal, or with 5.25 pounds of ground shelled corn plus 0.75 pound of soybean oilmeal, in order to obtain growth rates in heifers of 1.10 and 1.11 pounds per day, respectively. Lower levels of supplementation resulted in poor growth rates.

Davis et al. (3) reported, in summarizing the results of 2 years of experimentation, that heifers fed good-quality hay and silage gained 1.54 pounds per day when given a supplement of 6 pounds of molasses plus 1.1 or 1.2 pounds of soybean oilmeal, as compared with 1.41 pounds per day when

\footnotetext{
${ }^{1}$ Associate Nutritionist, Agricultural Experiment Station, University of Puerto Rico, Substation, Lajas, P.R.

${ }^{2}$ Italic numbers in parentheses refer to Literature Cited, pp. 131-2.
} 
given a supplement of 4.0 or 4.8 pounds of ground shelled corn plus 0.4 pound of soybean oilmeal.

King et al. (4) reported daily gains of 1.34 pounds in heifers which consumed 5.9 pounds of molasses, and 1.46 pounds in heifers which consumed 5 pounds of ground shelled corn in addition to good-quality grass hay. Cottonseed oilmeal was used to equalize the protein intakes under both rations.

The usefulness of molasses as an energy source for cattle is apparently limited by the fact that its content of net energy for productive purposes decreases as the quantity fed increases beyond a certain maximum. Lofgreen and coworkers have established this critical maximum at a level representing slightly more than 10 percent of the total ration in beef heifers, beef steers, and lactating dairy cows $(6,7,8)$.

Another reported disadvantage of including large quantities of molasses in the ration is the tendency of molasses to decrease utilization of the available nitrogen. King et al. (5) found that the addition of 3 pounds of molasses to a dairy heifer ration consisting of good-quality silage and 2 pounds of cottonseed oilmeal decreased crude-protein digestibility from 59.7 to 51.0 percent. In other studies, bull calves and steers fed large amounts of molasses digested less crude protein and retained less of the nitrogen digested than when fed similar rations with ground shelled corn (2,3).

\section{EXPERIMENTAL PROCEDURE}

\section{ANIMALS}

Six Brown Swiss and six Holstein heifer calves, born at the Lajas Substation and weaned not later than 9 weeks of age, were used in the experiment. They were assigned alternately to one of two experimental rations as they reached the age of 127 days, which occurred during the months from November 1964 to April 1965.

\section{HOUSING}

The experimental animals were housed in an open-air calf and heifer barn in individual pens with concrete floor and wire-screen partitions during the entire experiment. Each pen was equipped with manger and water bucket and allowed access to an outside exercise runway that was unpaved.

\section{EXPERIMENTAL DESIGN AND STATISTICAL ANALYSIS}

Each heifer began the experiment at the age of 127 days and completed it at the age of 367 days. The overall experiment of 240 days was divided into eight periods of 30 days each. The two rations constituted the experimental treatments. Three heifers of each breed were assigned to each ration. The experiment was analyzed as a randomized-block design with replicates. 
Analysis of variance was performed according to standard procedures, in order to separate the variance due to the following sources: Rations, breeds, ration $\times$ breed interaction, and residual. The data pertaining to live-weight gain were analyzed for each 30-day period separately and for the experiment as a whole, whereas the forage-consumption data were analyzed for the whole experiment only.

TABLE 1.-Feeding schedule, expected total digestible nutrients, and digestible protein contents (pounds) of the 2 rations, and requirements of the heifers

\begin{tabular}{|c|c|c|c|c|c|c|c|c|c|}
\hline $\begin{array}{l}\text { Period } \\
\text { No. }\end{array}$ & Ration & $\begin{array}{c}\text { Concen- } \\
\text { trates } \\
\text { mixture }\end{array}$ & $\begin{array}{l}\text { Soybean } \\
\text { oilmeal }\end{array}$ & Molasses & Forage & $\underset{\text { TDplied }}{\text { Sup }}$ & $\begin{array}{c}\text { Required } \\
\text { TDN }^{2}\end{array}$ & $\underset{\text { DP1 }^{1}}{\text { Supplied }}$ & $\underset{\mathrm{DP}^{2}}{\text { Required }}$ \\
\hline \multirow[t]{2}{*}{1} & I & 5 & 0 & 0 & 5 & 4.5 & 4.2 & 0.64 & 0.62 \\
\hline & II & 3 & .6 & 2 & 5 & 4.5 & & .68 & \\
\hline \multirow[t]{2}{*}{2} & I & 5 & 0 & 0 & 7 & 4.8 & 4.7 & .66 & .65 \\
\hline & II & 2 & .8 & 3 & 7 & 4.8 & & .67 & \\
\hline \multirow[t]{2}{*}{3} & I & 5 & 0 & 0 & 9 & 5.1 & 5.2 & .67 & .69 \\
\hline & II & 1 & 1.0 & 4 & 9 & 5.0 & & .65 & \\
\hline \multirow[t]{2}{*}{4} & I & 5 & 0 & 0 & 12 & 5.5 & 5.7 & .70 & .73 \\
\hline & II & 0 & 1.2 & 5 & 12 & 5.4 & & .65 & \\
\hline \multirow[t]{2}{*}{5} & I & 5 & 0 & 0 & 15 & 6.0 & 6.2 & .72 & .77 \\
\hline & II & 0 & 1.2 & 5 & 15 & 5.9 & & .67 & \\
\hline \multirow[t]{2}{*}{6} & I & 5 & 0 & 0 & 19 & 6.6 & 6.6 & .75 & .80 \\
\hline & II & 0 & 1.2 & 5 & 19 & 6.5 & & .71 & \\
\hline \multirow[t]{2}{*}{7} & I & 5 & 0 & 0 & 23 & 7.2 & 7.1 & .78 & .81 \\
\hline & II & 0 & 1.2 & 5 & 23 & 7.1 & & .74 & \\
\hline \multirow[t]{2}{*}{8} & I & 5 & 0 & 0 & 28 & 7.9 & 7.5 & .82 & .82 \\
\hline & II & 0 & 1.2 & 5 & 28 & 7.8 & & .78 & \\
\hline
\end{tabular}

1 Total digestible nutrients and digestible protein calculated from feed-composition tables (10).

2 TDN and DP requirements according to National Research Council (11), assuming a starting weight of $220 \mathrm{lb}$. and average live-weight gains of $35 \mathrm{lb}$. per 30 day period.

\section{RATIONS}

The same harvested forage was employed in both experimental rations. Green chopped sugarcane (Sacharum oficinarum) was used during part of the first 30-day period of the first two heifers to begin the experiment, because silage was not available at that time. During the rest of the experiment the forage used was either sugarcane silage prepared without preservative, or sorghum (Sorghum vulgare) silage prepared with a molasses preservative. The same quantities of forage were offered to all the experimental animals, and were increased from 5 pounds daily during the first 30-day period to 28 daily during the eighth 30 -day period (table 1). Fairly small 
allowances were employed in the hope of achieving nearly complete consumption of all forage offered. Pasture was not included in the rations because it was desired to have a complete record of all feed consumed. Since harvested forages of various types were to be used, it was necessary to employ a rough estimate of what their average contents of total digestible nutrients (TDN) and digestible protein (DP) would be. The estimates employed were 15 and 0.8 percent, respectively, as fed.

Ration I was supplemented throughout the experiment with 5 pounds of a conventional concentrates mixture having the following percentage composition: Ground shelled corn, 30.5; yellow hominy feed, 30.5; blackstrap molasses, 12.5; dehulled soybean oilmeal, 10.0; tuna fishmeal, 5.0; and salt, 1.5. Ration II was supplemented with the following quantities of the conventional concentrates mixture, dehulled soybean oilmeal, and blackstrap molasses, respectively-3.0, 0.6, and 2.0 pounds during the first 30 day period; $2.0,0.8$, and 3.0 pounds during the second 30 -day period; 1.0 , 1.0 , and 4.0 pounds during the third 30 -day period; and $0,1.2$, and 5.0 pounds during the remainder of the experiment. This procedure of gradually replacing the concentrates mixture with molasses and soybean oilmeal was intended to avoid possible digestive disturbances. Molasses was fed by pouring it on top of the silage. The concentrates mixture, soybean oilmeal, and molasses were assumed to contain $75.5,79.0$, and 54.0 percent TDN, and $12.0,46.2$, and 0 percent DP, respectively.

Both of the experimental rations were planned to provide approximately the required amounts of TDN and DP for normal growth of replacement heifers (table 1). Comparing ration I with ration II, the latter was expected to supply slightly more DP in periods 1 and 2 , while the former was expected to supply slightly greater amounts of both TDN and DP in periods 3 through 8.

Samples of the concentrate feeds and silages used in this experiment were taken periodically and subjected to proximate chemical analysis according to A.O.A.C. procedures (1). The molasses was subjected only to specific gravity determination.

\section{LIVE-WEIGHT DETERMINATIONS}

The experimental animals were weighed to the nearest pound on the day they began the experiment, and thereafter on eight occasions at the completion of each consecutive 30-day period. Each weighing was done before feeding in the morning. Before each weighing except the first the heifers spent at least the preceding 14 hours with neither feed nor water available. Before the first weighing they spent the night on pasture. 


\section{RESULTS}

It had been anticipated that the average initial live-weight of the heifer calves beginning the experiment would be about 220 pounds. This estimate was slightly low, as the initial live-weights averaged 238 and 240 pounds in the animals assigned to rations I and II, respectively. The Brown Swiss heifers averaged 235 pounds and the Holsteins 243 pounds.

\section{GROWTH}

The average daily live-weight gains of the heifers of both breeds consuming ration I ranged from 0.81 to 1.37 pounds during individual 30-day

TABLE 2.-Average daily live-weight (pounds) gains of heifers during successive 80-day periods and during the entire experiment

\begin{tabular}{c|r|r|r|r|r|r}
\hline \multirow{2}{*}{ Period } & \multicolumn{3}{|c|}{ Ration I } & \multicolumn{3}{c}{ Ration II } \\
\cline { 2 - 6 } & Brown Swiss & Holstein & Both breeds & Brown Swiss & Holstein & Both breeds \\
\cline { 2 - 6 } 1 & 1.17 & 0.62 & 0.89 & 0.92 & 0.64 & 0.78 \\
2 & 1.22 & .72 & .97 & 1.10 & 1.32 & 1.21 \\
3 & 1.18 & 1.57 & 1.37 & .87 & 1.14 & 1.01 \\
4 & .93 & 1.20 & 1.07 & .74 & .69 & .72 \\
5 & 1.28 & 1.14 & 1.21 & .83 & 1.10 & .97 \\
6 & .97 & .65 & .81 & .44 & .39 & .42 \\
7 & 1.18 & .59 & .88 & .43 & .62 & .53 \\
8 & .64 & 1.17 & .91 & .22 & .71 & .47 \\
\hline \multirow{2}{*}{ Entire experiment } & 1.07 & 0.96 & $1.01^{1}$ & 0.70 & 0.83 & 0.76 \\
\hline
\end{tabular}

${ }^{1}$ Difference between rations significant $(P<.05)$.

periods (table 2). The average for the whole experiment was 1.01 pounds. The heifers of both breeds consuming ration II ranged in average daily live-weight gain during individual periods from 0.42 to 1.21 , while averaging 0.76 pound for the whole experiment. The difference in average live-weight gain was in favor of ration I in all except period 2, but it was not significant for any of the individual periods because of large within-ration variation. During the whole experiment, however, the rate of gain under ration I was significantly $(P<.05)$ greater than under ration II.

Live-weight gains showed considerable variation between breeds within rations during several individual 30 -day periods, with the difference being sometimes in favor of one breed and sometimes of the other. However, the effect of breed, or of ration $\times$ breed interaction, was not significant during any of the individual periods. During the whole experiment the effect of breeds, disregarding treatments, was practically nil. The Brown Swiss 
heifers performed slightly better than the Holstein heifers on ration I, whereas on ration II the opposite apparent effect of breeds was observed. This effect was not sufficiently consistent to result in a significant ration $X$ breed interaction, however.

A linear regression analysis was performed to determine the effect of initial live weight on live-weight gain during the whole experiment. The results showed a tendency for the heifers which weighed less at the start to gain faster, though the magnitude of the effect was slight $(b=-1.05)$ and not significant.

\section{HEALTH}

The only health abnormality encountered was diarrhea in one of the Holstein heifers fed ration I. This heifer had diarrhea on three separate occasions for a total of 35 days. The condition probably had an adverse effect on live-weight gain. During the whole experiment the affected animal averaged 0.21 pound less daily gain than the other animals fed the same ration (0.84 vs. 1.05).

\section{FEED CONSUMPTION AND COMPOSITION}

Nearly all of the concentrates mixture, soybean oilmeal, and molasses offered to the experimental animals was consumed, as the feed refusals recorded constituted less than 0.5 percent of that fed in each instance (table 3). The average total forage consumptions per heifer on rations I and II were 3,310 and 3,038 pounds, respectively. These figures reflect forage refusals amounting to 6.5 and 14.2 percent of that fed, respectively. The Holstein heifers on both rations consumed more forage than the Brown Swiss heifers (3,304 vs. 3,045 pounds). Neither rations nor breeds significantly affected forage consumption, though the effect of rations approached significance at the 5-percent level of probability.

The average percentages of proximate components determined in the concentrates mixture, soybean oilmeal, sugarcane silage, and sorghum silage, respectively were as follows: Dry matter, 87.5, 91.7, 24.8, and 23.8; crude protein, $14.1,45.3,0.9$, and 1.5 ; ether extract, $3.2,1.8,0.5$, and 0.6 ; crude fiber, 1.9, 2.5, 9.0, and 8.8; ash, 5.4, 5.5, 1.6, and 2.5; and nitrogen-free extract, $62.9,36.6,12.8$, and 10.4 . The specific gravity of the molasses was determined as 1.37 .

\section{FEED COSTS}

An accounting of feed costs was made by assuming the following costs per 100 pounds for the feeds employed in this experiment: Concentrates mixture, $\$ 3.85$; soybean oilmeal, $\$ 5.88$; molasses, $\$ 1.75$; and harvested forage $\$ 0.50$. The figure given for the concentrates mixture includes both 
the cost of ingredients and the expenses involved in preparing it at the substation. Over the entire experiment ration II resulted in a saving in total feed costs of $\$ 8.00$ per heifer as compared with ration I (table 3). Of the amount saved, $\$ 1.36$ was attributable to less forage consumption under ration II, and $\$ 6.64$ to lower cost of the supplements employed in this ration. The average saving in feed cost per heifer per day on ration II was 3 cents. However, when the total feed costs were divided by the total pounds of live-weight gained under each ration, it was found that the

TABLE 3.-Consumption of feeds during the entire experiment and corresponding feed costs

\begin{tabular}{|c|c|c|c|c|}
\hline \multirow{2}{*}{ Data on feeds utilized } & \multicolumn{2}{|c|}{ Ration I } & \multicolumn{2}{|c|}{ Ration II } \\
\hline & All 6 heifers & $\begin{array}{l}\text { Average per } \\
\text { heifer }\end{array}$ & All 6 heifers & $\begin{array}{l}\text { Average per } \\
\text { heifer }\end{array}$ \\
\hline \multicolumn{5}{|l|}{ Concentrates mixture } \\
\hline Amount consumed.......lb. & $7,187.6$ & $1,197.9$ & $1,078.0$ & 179.7 \\
\hline Cost............. dol. & 276.72 & 46.12 & 41.50 & 6.92 \\
\hline Soybean oilmeal & & & & \\
\hline Amount consumed ......lb. & 0 & 0 & $1,509.6$ & 251.6 \\
\hline Cost.............. dol. & 0 & 0 & 88.76 & 14.79 \\
\hline Molasses & & & & \\
\hline Amount consumed .......lb. & 0 & 0 & $6,091.3$ & $1,015.2$ \\
\hline Cost . . . . . . . . . . dol. & 0 & 0 & 106.60 & 17.77 \\
\hline \multicolumn{5}{|l|}{ Forage } \\
\hline Amount consumed ........ Ib. & $19,863.1$ & $3,310.5$ & $18,224.5$ & $3,037.4$ \\
\hline Cost............... dol. & 99.32 & 16.55 & 91.12 & 15.19 \\
\hline Total feed costs. . . . . . . do. & 376.04 & 62.67 & 327.98 & 54.67 \\
\hline Average feed costs per day.do. & 1.57 & .26 & 1.37 & .23 \\
\hline Total live-weight gain. .....lb. & $1,461.0$ & 243.5 & $1,097.0$ & 182.8 \\
\hline $\begin{array}{l}\text { Feed costs per pound of live- } \\
\text { weight gain } \ldots \ldots \ldots \ldots \text { dol. }\end{array}$ & .26 & .26 & .30 & .30 \\
\hline
\end{tabular}

average cost of producing a pound of live-weight gain was 4 cents higher under ration II than under ration I.

\section{DISCUSSION}

The average daily live-weight gain of 1.01 pounds by the heifers fed ration I ( 1.05 pounds, if the heifer affected by diarrhea is excluded) can be considered a barely adequate growth rate for replacement heifers. Average daily live-weight gains specified in published growth standards for Holstein heifers during the interval from 6 to 12 months of age include a value of 1.01 pounds from New Zealand, and values ranging from 1.12 to 1.74 pounds for temperate North America, according to the summary of Martin et al. (9). 
The growth rate obtained with ration I in the present experiment was slightly less ( $1.01 \mathrm{vs} .1 .11$ pounds per day) than that obtained in a previous study at this substation with dairy heifers (12), in which the ration consisted of forages of similar quality fed in comparable amounts, plus 6 pounds of a simple-formula concentrates mixture, not greatly different from the one used in the present experiment. The feed costs per pound of live-weight gain in the present study were less than in the previous study ( $\$ 0.26$ vs. $\$ 0.38$ ) because of lower unit cost of the concentrates mixture, the use of less concentrates mixture, and the elimination of manually harvested green forages from the ration.

The average daily live-weight gain of 0.76 pound in the heifers fed ration II definitely represents an inadequate growth rate. The inferior performance of the ration II heifers began in period 3 when their daily allowance of molasses was increased to 4 pounds and that of concentrates mixture was reduced to 1 pound, and continued during periods 4 through 8 when they received 5 pounds daily of molasses, and no concentrates mixture.

Several factors may have contributed to the reduced growth rate of the heifers fed ration II as compared with that of the heifers fed ration I. The latter group began to consume more forage than the former in period 4 , and continued to do so thereafter. During periods 4 through 8 the average daily forage consumptions by the heifers fed rations I and II were 22.5 and 20.2 pounds, respectively. Other published reports of experiments with dairy heifers have not demonstrated any tendency for forage consumption to decline when molasses was substituted for ground shelled corn $(2,3)$.

It became obvious upon chemical analysis that the DP value of 46.2 percent assumed for the soybean oilmeal in planning the experimental rations was an overestimate. The crude-protein content was found to be only 45.3 percent; thus the expected DP content would be about 41 or 42 percent. This experience emphasizes the desirability of formulating experimental rations based on actual chemical analyses of the feeds to be employed rather than on published figures. On the other hand, the DP value of 12 percent assumed for the concentrates mixture appears reasonable, as chemical analysis showed the mixture to contain 14.1 percent of crude protein. If 12.0 and 41.5 percent are reasonable estimates of the DP contents of the concentrates mixture and soybean oilmeal, respectively, then in periods 4 through 8 the 5 pounds of concentrates mixture in ration I supplied 0.6 pound DP, whereas the 1.2 pounds of soybean oilmeal in ration II supplied only 0.5 pound DP. The DP available to the heifers fed ration II may have been reduced further by the effect of molasses in decreasing crude-protein digestibility $(2,3,5)$.

In the present experiment molasses was expected to contribute 24,34 , $43,50,46,42,38$, and 34 percent of the TDN supplied by ration II in 
periods 1 through 8 , respectively. At these high levels of molasses supplementation the efficiency of utilization of the energy contained in the molasses for growth may have been depressed $(6,7)$. However, in order to compare directly the concentrates mixture with the molasses supplemented with soybean oilmeal as energy sources, it would be necessary to eliminate differences in forage consumption and to equalize the DP contents of the two rations.

The results of this experiment indicate that a high level of molasses, even when fed with an amount of soybean oilmeal approximately sufficient to meet the minimum DP requirements, does not correct the nutritional inadequacy of a ration based upon poor-quality forage for dairy heifers younger than 12 months of age. The use of the cheaper ration II did not result in any real feed economy, since feed costs per pound of live-weight gain were greater with this ration than with ration I. Bohman et al. (2) also reported inefficient use of molasses by growing dairy heifers fed poorquality forage. More efficient use of molasses might be expected if it were fed with good-quality forage, as was found by Davis et al. (3) and King et al. (4).

\section{SUMMARY}

Six Brown Swiss and six Holstein heifers were assigned to one of two experimental rations as they reached 127 days of age, for use in an experiment involving a randomized block design. The 240-day experiment was divided into 8 periods of 30 days each. The heifers were fed individually. Both rations included the same harvested forages, principally sorghum silage or sugarcane silage, the daily allowance of which increased from 5 pounds in period 1 to 28 pounds in period 8 .

In ration $I$ the forage was supplemented with 5 pounds of a conventional concentrates mixture throughout the experiment. In ration II the daily allowance of concentrates mixture was reduced from 3 pounds in period 1 to 0 in period 4, while the daily allowances of blackstrap molasses and of dehulled soybean oilmeal were increased from 2 to 0.6 pounds, respectively, in period 1 to 5 and to 1.2 pounds, respectively, in period 4, at which level they remained until the end of the experiment. Both experimental rations were expected to supply approximately the amounts of total digestible nutrients and digestible protein needed for normal growth of heifers, according to published feed analyses and published nutrient requirements.

Considerable variation in growth rate was found for individual 30-day periods on both rations. During the whole experiment the heifers which consumed ration I gained significantly $(P<.05)$ more than the heifers which consumed ration II (1.01 vs. 0.76 pounds per heifer per day). The former growth rate can be considered barely adequate, while the latter is de- 
finitely not adequate. Part of the poor growth rate in the heifers fed ration II can be ascribed to a lower total forage consumption per heifer than in the heifers fed ration I (3,304 vs. 3,045 pounds). Ration II was adversely affected by an overestimation of the digestible protein content of the soybean oilmeal in planning the rations, which was revealed by subsequent chemical analysis. Judging from other published reports, the high levels of molasses employed in ration II may have lowered the amount of net energy for growth contributed per pound of molasses, and decreased the crude-protein digestibility of the whole ration.

The following feed costs were calculated under rations I and II: Average costs per heifer per day, $\$ 0.26$ and $\$ 0.23$; and cost per pound of live-weight gain $\$ 0.26$ and $\$ 0.30$, respectively. The results suggested that the use of a high level of molasses supplemented with a minimal amount of soybean oilmeal as a substitute for all other concentrate feeds in rations based on poor-quality forage for heifers under 12 months of age, is neither nutritionally satisfactory nor economically advantageous.

\section{RESUMEN}

$\mathrm{Al}$ cumplir 127 días de edad, se asignaron seis novillas de la raza Pardo Suiza y seis de la Holstein a consumir una u otra ración experimental, para llevar a cabo una investigación que comprendió un diseño de bloques al azar. El experimento duró 240 días y se dividió entre 8 períodos de 30 días cada uno. Las novillas se alimentaron individualmente. Ambas raciones incluían el mismo forraje cosechado, mayormente ensilaje de millo o ensilaje de caña. La ración forrajera diaria aumentó de 5 libras en el período 1 hasta 28 libras en el período 8. En el caso de la ración I, el forraje se suplementó con 5 libras de una mezcla convencional de alimentos concentrados durante todo el experimento. En el caso de la ración II, la ración diaria de la mezcla de alimentos concentrados se redujo de 3 libras en el período 1 a nada en el período 4, mientras que se aumentaron las raciones diarias de miel de purea y de harina de soja sin cáscara de 2 y 0.6 libras, respectivamente, en el período 1 a 5 y 1.2 libras, respectivamente, en el período 4, quedando así hasta terminar el experimento. Se esperaba que ambas raciones experimentales suplieran aproximadamente las cantidades de nutrimentos totales digeribles y de proteína digerible requeridas para el crecimiento normal de las novillas, según los datos publicados concernientes a los análisis de los alimentos y a los requerimientos para una adecuada nutrición de los animales.

Se encontró que hubo mucha variación en el ritmo de crecimiento de los animales durante los períodos individuales de 30 días bajo ambas raciones. Durante todo el experimento las novillas que consumieron la ración I ganaron significativamente más en peso $(P<.05)$ que las que consumieron 
la ración II (1.01 contra 0.76 libras por novilla por día). La primera representa una ganancia que puede considerarse escasamente adecuada, mientras que la última definitivamente no lo es. Parte de la causa de la ganancia inferior de las novillas bajo la ración II puede atribuirse a un consumo menor del total de forraje por novilla que en las novillas bajo la ración I (3,304 contra 3,045 libras). El sobreestimado del contenido de proteína digerible de la harina de soja, al planear las raciones, afectó adversamente la ración II lo cual luego se descubrió mediante el análisis químico. A juzgar por otros resultados publicados, puede ser que los niveles altos de miel en la ración II causaran una reducción de la cantidad de energía neta para el crecimiento, suplido por libra de miel, y que redujo la digestibilidad de la proteína cruda en la ración entera.

Se calcularon los siguientes costos de alimentación bajo las raciones I y II. El costo promedio por novilla por día fue de $\$ 0.26$ y $\$ 0.23$ respectivamente; y el costo por libra de ganancia en peso vivo, de $\$ 0.26$ y $\$ 0.30$, respectivamente. Se concluyó que el uso de un nivel alto de miel suplementado con una cantidad mínima de harina de soja, como sustituto para todos los otros alimentos concentrados en raciones a base de forraje de baja calidad para novillas menores de 12 meses de edad, no es satisfactorio desde el punto de vista de la nutrición ni rinde beneficio alguno.

\section{LITERATURE CITED}

1. Asoc. Official Agr. Chem., Official Methods of Analysis, 9th ed., Washington, D.C., 1960.

2. Bohman, V. R., Trimberger, G. W., Loosli, J. K., and Turk, K. L., The utilization of molasses and urea in the rations of growing dairy cattle, J. Dairy Sci. 37 (3): 284-93, 1954.

3. Davis, R. F., Trimberger, G. W., Turk, K. L., and Loosli, J. K., Feeding Value and Digestibility of Cane Molasses Nutrients for Dairy Heifers, N.Y. Agr. Exp. Sta. Bull. 914, 1955.

4. King, W. A., Brannon, C. C., and Webb, H. J., Feeding molasses with hays to dairy heifers and milking cows, J. Dairy Sci. 43(6): 889, 1960.

5. King, W. A., O'Dell, G. D., and Roderick, D. B., Utilization of blackstrap molasses, urea in molasses, and ammoniated molasses by dairy heifers, J. Dairy Sci. 40(7): 810-17, 1957.

6. Lofgreen, G. P., Net energy of fat and molasses for beef heifers with observations on the method for net energy determination, J. Anim. Sci. 24(2): 480-7, 1965.

7. Lofgreen, G. P., and Otagaki, K. K., The net energy of blackstrap molasses for fattening steers as determined by a comparative slaughter technique, J. Anim. Sci. 19(2): 392-403, 1960.

8. - - , and - , The net energy of blackstrap molasses for lactating dairy cows, J. Dairy Sci. 43(2): 220-30, 1960.

9. Martin, T. G., Jacobson, N. L., McGilliard, L. D., and Homeyer, P. G., Factors related to weight gain of dairy calves, J. Dairy Sci. 45 (7): 886-92, 1962.

10. Morrison, S. H., 1964-65 Ingredient analysis and estimated feed value tables for beef, sheep rations, Feedstuffs $36(51): 52-8,1964$. 
132 JOURNAL OF AGRICULTURE OF UNIVERSITY OF PUERTO RICO

11. National Research Council, Committee on Animal Nutrition, Nutrient Requirements of Domestic Animals, III, Nutrient Requirements of Dairy Cattle, Natl. Acad. Sci.-Natl. Res. Council Pub. 464, 1958.

12. Randel, P. F., Comparison of simple vs. complex concentrate mixtures for dairy cattle in Puerto Rico: Feeding heifers in dry lot.J. Agr. Univ. P.R. $49(3): 342-$ 9, 1965. 